\title{
RE- BRANDING: Study on the repositioning of Banco Intermedium (Banco Inter)
}

\author{
Juliana Lopes de Almeida Souza \\ Rachel Farias do Patrocínio \\ Mariana de Oliveira Costa
}

\section{Samara de Oliveira Sá}

\begin{abstract}
This study addresses the brand repositioning of Banco Intermedium. The objective of the study was to understand what the brand positioning was like for some years and how it has been working its repositioning since 2017. We also seek to investigate how the repositioning contributed to the improvement of the institution's image and performance in the marketplace. As a methodology, secondary data searches were adopted through the Internet, through the brand's websites and online social networks, and as a method for obtaining primary data, interviews were conducted with clients, and with a branding specialist and employee of Banco Inter, in order to understand the internal and external perception of the brand.
\end{abstract}

Keywords: Brand, Brand, Repositioning, Digital, Bank

\section{INTRODUCTION}

The brand redesign and management (rebranding) project involves tangible and intangible values, and has several stages which contemplate conducting interviews and research that consider economic, political and social factors. Rebranding is a strategy that allows a company to modify its denomination, its visual identity, language, values, among other identifying elements, or to make more than one modification at the same time to form a new identity. The rebranding process also makes possible to correct failures, adapt better to the market and further align the positioning with the company's culture (KOTLER AND KELLER, 2006).

Given the context presented, the object chosen for this study was Banco Intermedium, created in 1994 in Brazil. The institution, from Minas Gerais, started its career as a financial company of the MRV group, and in 2008, became a multiple bank recognized by the Central Bank of Brazil. Banco Intermedium has always been a consolidated institution however, even with a great technological and digital aspect to it, the bank remained with the same old presentation of its origin, which conveyed the idea of being conservative and not at all jovial. Given this, it underwent a repositioning process and, in 2017, adopted a new name and has been standing out in the segment for offering $100 \%$ digital and totally free banking services.

In this sense, the problem of this study is to answer the following question: How has the repositioning of Banco Inter's brand changed its strategic visibility in its market segment? For this reason, its general objective is to analyze the changes that occurred inside and outside the institution, with brand repositioning. For this analysis, changes related to the recognition of Intermedium and Inter brands are considered; the communication of the institution; the relationship with customers and employees; physical structures; and the relationship with the market. And, as specific objectives: describe the history of the brands both Intermedium and 
Inter; identify the reasons that led to the repositioning process, raise the first actions adopted during the implementation of the new positioning; and perform analysis of primary and secondary data in order to survey the results achieved and whether the institution's values are being conveyed by its communication to gain market visibility.

\section{BRANDING: BRAND ELEMENTS}

According to Keller and Machado (2006), brand elements are the resources it possesses that serve to identify and differentiate it. There are six criteria for choosing brand elements, which are identified as: Significance, Memorability, Attractiveness, Transferability, Adaptability and Protection. Such elements can be chosen to build as much brand equity as possible.

Significance, memorability, and attractiveness are criteria that can be considered as a brand building process, and refer to the way brand equity is built when choosing brand elements. Transferability, adaptability, and protection are more defensive in nature, and are related to how a brand element can be protected.

According to the authors Keller and Machado (2006), significance is related to the meanings that brand elements convey in relation to the formation of brand associations. The meanings of these elements can take on different meanings, both in descriptive and persuasive content.

Memorability, for Keller and Machado (2006), within the brand context, has become an essential requirement for building brand equity and achieving brand recall. Brand elements should be striking for ease of recognition at the time of purchase. Names, symbols and logos are important in this process, so that visual impressions attract more consumer attention and are marked in their memory.

Attractiveness is related to how attractive the brand is. For Keller Machado (2006), consumers are not focused on analyzing a lot of information when making purchase decisions; they are based on the attractiveness of the brand and its constituent elements. Transferability explains that the less specific brand name contributes to its transferability between different categories. That is, the name can be used to identify product brands in different segments.

For the authors Keller and Machado (2006), adaptability of the brand element happens constantly over time, and lead into changes. In this context, it can be argued that brand elements must be adaptable and flexible to change so that they are easier to update. Protection is related to the extent to which the brand element can be protected, both legally and competitively.

\section{KAPFERER IDENTITY PRISM}

Understanding some concepts helps increasing rigor in the analysis of brand repositioning. A very important concept for building brand equity is brand identity - a collection of defining characteristics, as a kind of "brand DNA". The Brand Identity Prism, created by the Frenchman Jean-Noël Kapferer (1991), is based on the premise that the strategic construction of a brand identity can lead to increased brand equity.

Kapferer (apud PEREIRA, 2017) suggests that identity would be composed of six facets that relate to one of two dimensions of the vertical level of the model structure: Exteriorization and Interiorization. And to understand how the prism works, it is important to examine what each facet represents. 
The facets of exteriorization are: (a) Physical - refers to the set of physical characteristics that a brand carries, such as the raw material, logo, colors, design, attributes strongly associated with the brand; that is, the physical aspect is functional and tangible. This is usually the most obvious aspect of the brand, and the most remembered by the consumer. (b) Relationship - is the ability of a brand to become a source of relationship, providing the opportunity for intangible exchanges, ie refers to the experience that the brand provides the consumer. (c) Reflex - the brand reflects the consumer's image. As it is often mistaken by consumers, it is important to note that the reflection is the image the target audience has of the brand to which it relates. Proper management of this reflex makes the brand most desired for consumers.

In turn, those of interiorization are: (d) Personality - refers to the humanization of the brand. According to Kapferer (apud PEREIRA, 2017, p.31) is the "type of persona to which the brand could be compared, as archetypes and their intimate characteristics, as their values and character". In this respect, the brand is described through adjectives normally attributed to people, making the psychology approach to describe the personality of the brand in the perception of consumers appropriate. (e) Culture - refers to the culture of the brand itself. This facet can be described as a value system, a source of inspiration and brand energy. Culture is responsible for guiding all forms of brand manifestation (products, services and communication). This is because culture reinforces the behavioral side of the brand and is thus able to connect it with the organization, maintaining strong links with the products and services offered; and establishing guidelines for the entire process of brand communication with its consumers. (f) Mindset - refers to the consumer's internal mirror. According to Kapferer (apud PEREIRA, 2017) through the consumption of certain brands, the consumer creates an image of himself. From this point, the consumer projects his image to the outside through the brand and creates a form of dependence on it; This facilitates communication between them.

The model also considers two more dimensions of the horizontal level of the structure, which reflect the way these facets of the brand are transmitted to its audiences: Constructed Issuer and Constructed Recipient.

Thus, according to Kumar and Srivastava (apud PEREIRA, 2017), the Physical and Personality facets are totally controlled by the issuer. The Reflection and Mindset facets are controlled by the brand recipient. And finally, the Relationship and Culture facets are mediators and therefore controlled by both. Thus, the brand should aim to articulate all dimensions in order to identify their strengths and weaknesses; "Manipulating" facets in ways that enhance their tangible and intangible values.

According to Kotler and Keller (2006), the repositioning of a brand is important, because through it, it will be possible to reach new markets, overcome a crisis, or even adapt to changes in consumer preferences and habits, as well as the emergence of new competitors and technologies, for example, that can greatly affect a brand's success rate.

Within the marketplace it is possible to find consolidated brands that have experienced difficulties at some point. Some have disappeared, and others have recovered by restoring or establishing the sources of brand equity (KOTLER and KELLER, 2006). The process is considered positive because it shows that the brand is willing to attract new audiences or renew its product portfolio, for example. 


\section{METHODOLOGICAL PROCEDURES}

This item describes the methodological process that was developed for the study. Laville and Dionne (1999, p.11) state that the methodology is fundamental, and that it is important to "work rigorously, with method, to assure yourself and others that research results are reliable, valid". In this part of the research, we demonstrate the methods and procedures that are used to search and analyze the data. For this, it is important to highlight that, at first, the contextualization of the themes, concepts and approaches was performed, aiming at understanding Banco Inter's brand positioning, but it was also necessary to search for information related to the brand history and its current coverage.

The present study has as methodological proposal to explore and analyze the empirical object, through the case study of the actions taken in the last years (2016 to 2019). This period includes the change of the brand positioning. Considering case study, Laville and Dionne (1999) report that, for a better understanding of the case, it is necessary to conduct in-depth interviews with the people who were protagonists of the event studied, who followed the decisions and actions taken, for example. In addition, you should also do shorter interviews with people who have been affected by the same event. Given this, after understanding the empirical object and the corpus of analysis, with the objective of deepening the knowledge of the concepts and applications of the chosen theme, a reading and analysis of existing bibliographic materials and secondary data about the institution was made available on the Internet. In addition, a study of comments and interactions on Banco Inter's online social networks was conducted to gain initial insight into the relationship between the brand and its customers.

Observational research identified the possibility of more in-depth information on the repositioning of Banco Inter's brand. Thus, the primary data analysis became essential to continue the development and understanding of the study, as it provided important information, which helped in understanding the problem, generating new questions and perceptions. Thus, it is understood that it was necessary to perform exploratory analyzes with clients of the institution and with a communication professional.

Unstructured interviews were also conducted: a focus group - held on May 22, 2019 discussed and explored customers' perceptions of the Intermedium and Inter brands; Furthermore the were interviews conducted on October 18, 2018 and April 29, 2019 - with professional Noele Karime, branding specialist and employee of Banco Inter. She was chosen for the interview because she was one of the people directly involved in the repositioning process, with the objective of obtaining the vision the institution itself about its brands and the process of change. The interviews lasted an average of 1 hour and, to ensure better use of the information obtained, all were duly captured in audio with the permission of the interviewees.

\section{THE INTER BRAND AND ITS REPLACEMENT}

According to information obtained on the institution's official websites, Banco Inter began its financial activities in 1994, under the name of Intermedium Financeira, based in Belo Horizonte / MG,Brazil and was founded by members of the Menin family, owner of the MRV Engenharia group. The institution's initial purpose was to boost real estate seling operations, but it eventually strengthened in the banking loan market.

In 2008, it became a multiple bank recognized by BACEN. From that moment on, the bank proposed some changes in its products and services offered. One of the most impactful and, which is part of the brand image today, is the availability of its $100 \%$ digital free of charge checking account in 2015 . With all the changes that occurred during its history, the institution 
felt the need to reformulate its image. before the public, deciding in 2016 to start its brand repositioning process, and after much research in June 2017 the institution changed its name from Intermedium to Inter. This process will be discussed later.

\section{ANALYSIS: INTERVIEWS WITH INTER'S MARKETING PROFESSIONAL}

Interviews with marketing professional Noele Karime, an employee of Banco Inter and a Branding specialist, were to discuss the institution's own view of its brands - Intermedium and Inter -, its repositioning process and its communication. Regarding the new positioning, the professional stated that the brand had the launch of the digital account in 2015, as the main reason. The idea of the change came from the board with the support of the institution's marketing department who saw a gigantic growth opportunity, but which at that time would not be successful without a change of position. The goal was to show the market and people in general the shift in the bank's purpose and business. The bank had transformed isteslf become since the launch of the account turning into the first 100\% digital and free in Brazil. In this sense, the brand, which had been created more than 20 years ago, did not match the future projected by the institution.

According to Karime, the Intermedium Bank had a "Latin name, a long name, (...) black mark, heavy, serious, it had the look of something conservative, traditional, even old"; and although the bank had a consolidated history, this image no longer talked to the public of the institution, which lived a digital reality. At that moment, the bank went into an identity crisis: “(...) we were one thing and our appearance said it was something else". Thus, the repositioning process began in 2016, when the bank had about 50,000 account holders. And after a diagnosis internal and external - made by a consulting firm in São Paulo, the construction of the new brand really began in January 2017.

The whole process was based on the idea of what the institution called the Banking Revolution, a way of verbalizing all the transformation that the institution advocated in its speech. The professional reported that the banking market has been maintained for over 500 years in the same way, since the emergence of the first bank in Italy, being considered something untouchable, because, after all, worked and took care of something very important and delicate: people's money. And although banks have become somewhat more modern, with the presence of ATMs, computers and applications, for example, it was still not possible to completely eliminate the branch structure, the need to move to a physical structure and faceto-face service. The purpose of this revolution was nothing more than a break in the marketplace and the way people related to financial institutions.

Asked about aspects of the new positioning, Karime said it was necessary to build a new identity, a new tone of voice; in order to break the serious and traditional image that banks had until then, and at the same time convey the pillars that underpin the institution - simplicity, transparency, partnership, experience and security.

The process, she said, took place in a very natural, fluid and comfortable way for her audiences. The name "Inter" was considered the best choice because it has the meaning of connection and connection, reinforcing the concept of digital and a close relationship with its customers. Being the prefix of the name Intermedium and being an affectionate nickname already used, maintains a relationship with the old name and brought the institution even closer to its audiences. Moreover, simplicity, being one of the pillars of the bank, should also be present in its name, so there would be no reason to keep a bureaucratic name and often difficult to speak. Like the name, the logo was changed, replacing the old-fashioned and rigid typography with a 
more relaxed and more rounded shape; the dark colors for a brighter one which today is a striking feature orange, as shown in Figure 1.

Figure 1 - Brand Change (Repositioning)
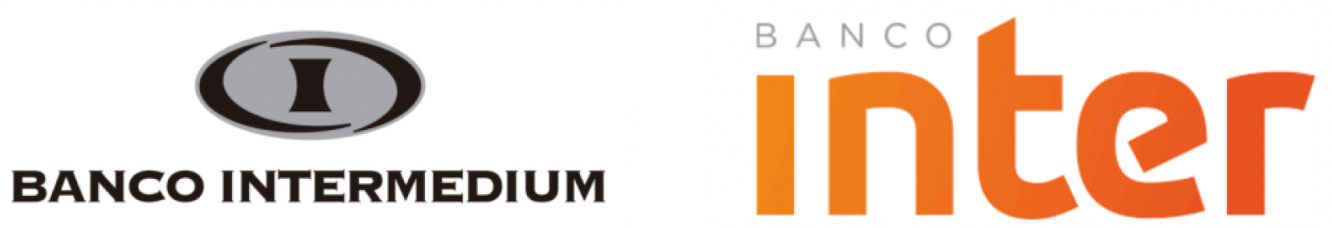

\section{Source: Brazilian Website Designers. Accessed on: 14 Oct 2018}

The color was already used, even in the days of Banco Intermedium, as a secondary color, and because it is vibrant, cheerful and warm, it was kept to convey the idea of closeness to people, of welcoming, of humanized care; As mentioned by the professional: "there is no such distance, we are the bank and they are the customers, we talk toe to toe". The different gradients and shades used bring out feelings, such as dynamism and movement, which can be translated into the constant changes and innovations that the bank is committed to delivering.

This transformation, too, needed to be reflected in the institution's tone of voice, both in written and verbal form; and despite adapting to each situation, the tone used has become lighter, close, friendly and easy to understand; once again, applying the pillars of the institution.

The implementation of the new positioning was another agenda discussed. On June 8, 2017, within 24 hours, the new brand was implemented and communicated to all stakeholders. The process was executed quickly, and attracted much attention from the market and the press. For the internal audience, a large one-day launch event was held, with various presentations and the distribution of various educational materials. They presented the reasons for the change, the new guidelines and the brand. During this same period, physical changes were made at the headquarters such as changing the nameplate of the institution and other endless substitutions, such as computer wallpapers and email addresses (@ bancointer.com.br). For the external public, advertising vehicles and the strong press disclosure about rebranding were used.

In another stage of the interviews, questions were addressed about the media used by the bank. As expected, the bank's performance is focused on the digital environment - application, email, websites and social media. You can actively see it on your pages and online social networks, where there are a large number of posts and interactions in comments and inbox. According to the professional, $80 \%$ of new customers come to the bank through digital media; Therefore, for the communication to work, there are teams dedicated to lead capture, performance, cross-selling, among others. Furthermore the institution has been expanding its communication offline, especially in urban media, such as subway wrapping, bus shelters and airport fingers. The partnership with the São Paulo football club also helped Banco Inter gain greater offline visibility, helping to boost brand awareness and increase its exposure.

Karime also highlights the growth of the institution after the repositioning, both in terms of structure - occupied 2 properties in the Cidade Jardim neighborhood and today there are 6 properties occupied by the bank - and number of employees - from 300 to about 1,300 
employees, as well as market visibility. and number of customers - increased from 50,000 (2016) to over 2 million (2019), as can be seen in the celebration post on Instagram on April $11,2019$.

All this growth proves that a brand need not go to the bottom to reposition itself, but must have the ability to identify an opportunity to better connect with people and the market.

\section{ANALYSIS: FOCUS GROUP}

Through the analysis of the official information of the institution and interviews with Noele Karime, it was noticed that, with the launch of the Digital Account, the bank started to have as main public Switchers, Millennials and Unbanked, therefore, to During the focus group, people who fit these characteristics were selected and are currently clients of Banco Inter.

The questions (APPENDIX E) to the focus group - consisting of five people of both sexes aged 23 to 38 - were aimed at discussing and further exploring customers' perceptions of the Intermedium and Inter brands. In addition to obtaining confirmation of the perception gained through the study of comments and interactions on online social networks.

Regarding the Intermedium brand, it was possible to identify that the brand was recognized by the majority of respondents. About how they got to know Banco Inter, 4 of the 5 participants in the group said it was through online social networks and account disclosures.

It was also argued about the advantages of being a customer, but some have not made any association with Intermedium Bank. It can be identified that everyone became clients approximately 1 or 2 years ago, ie, shortly after the change of brand, which took place in 2017, suggesting that the repositioning took effect and made the institution more recognized. When asked what motivated them to be customers, the group cited as main points: the exemption of fees; ease of account opening process and financial transactions; and the absence of the need for face-to-face care in solving various situations; that is, the fact that it is digital.

Regarding brand values, respondents who had prior knowledge of Banco Intermedium stated that there were no major changes, only improvements. They said, however, that the image the bank conveyed before the change did not speak to its reality, as it was an extremely modern, digital, simple and practical bank, but it it still carried the image of a traditional, serious and elite bank. In conclusion, repositioning made the institution's values more visible to the public.

When asked what was most striking about Inter's image, the group highlighted aspects such as innovation, confidence, safety and agility. In addition, the image of a bank thinking about its future, taking care of its image from the inside out, and this care is noticeable by the commitment and pride shown by its employees - verbalized through the expression "orange blood".

The increased visibility of the brand in the market after repositioning was noticeable to everyone, especially in the last two years, as some of them did not make any connection between the names Intermedium and Inter, or even knew the institution under the old name. Thus, despite offering the digital account since 2015, Banco Inter's recognition came mainly after the rebranding process.

When asked about the strengths and weaknesses of Banco Inter's recognition in the market, the interviewees highlighted the strength of the institution as strong - having been in the 
financial market for over 20 years and being in charge of a family that has several other successful businesses - and the elimination of bureaucracy in financial procedures - strongly present in traditional banks.

As a weakness, they stressed the "entry" into the market dominated by five other major financial institutions that currently hold most of the existing accounts. Even after the change, they consider the presence of the institution small compared to other banks.

Many interwiees believe that, despite being on the right track, much work will still be needed to gain a larger share of this digital banking market.

About the communication made by the bank, respondents rated it as very good. They cited care situations in which problems were resolved with agility and practicality. They consider it to be non-invasive communication without excessive promotion of services and products such as those of other banks; to them, Inter seems to understand and respect the digital customer profile; Therefore, it has made its communication light, relaxed, objective and easy to understand.

After repositioning it was identified from the group's reports that the way the bank communicates with its audiences seems to have changed; not only in relation to verbal contacts, which became friendlier, simpler and with less technical language, but also in visual communication, which through changing the primary color of the institution, the logo and the positioning of the company, became more cheerful, fun and dynamic. This change, which has happened in recent years, has led people to see the Inter brand and the possibility of becoming customers.

Regarding online social networks, most respondents follow the bank and describe the content as "interesting." They highlighted the presence of application tips and economy. One of the respondents (Edson) pointed out that the networks are very well worked, that the contents are segmented and planned for each profile, and are not published randomly, without a specific purpose.

\section{BANCO INTER: THE NEW POSITIONING}

Brands work from a positioning perspective, which boils down to branding strategies. Thus, the following are the brand elements, positioning and prism of identity perceived during the analysis of the Inter brand.

According to Keller and Machado (2006), the process of building a brand must consider six criteria: significance, memorability, attractiveness, transferability, adaptability and protection. Such elements can be worked on to increase brand equity as much as possible. Banco Inter has grown and strengthened in the financial market through branding strategies and their brand elements.

Significance of brand, the institution has its own name: the choice of the word "inter" was made in order to bring a meaning of connection to reinforce the partnership pillar, the digital concept and the good relationship with clients. The word is also the prefix of the name Intermedium and a loving way in which the public, especially the employees, already called the bank, creating a greater emotional bond.

Regarding the memorability of the brand it can be exemplified by the usability of the expressions "banking revolution" and the slogan "complete, digital and free". Throughout this 
study, these expressions and characteristics were translated into various forms in the interviews and researched media, and constantly remembered as a point of difference, in their position, in relation to the other banks.

Using elements of attractiveness, Inter presents in its campaigns, simple language to deal with a normally complicated subject and, thus, seeks to strengthen the relationship with the customer. Its communication is mainly focused on the light and relaxed digital environment, and even uses up-and-coming memes and their employees in publications to achieve a stronger interaction with their customers. In addition, the use of orange color, a warm tone that refers to creativity, joy, determination, attraction and success, is also pointed as a visual appeal of the brand.

Transferability is another brand element that Banco Inter has. This element refers to the ability to share brand elements across brand extensions such as Inter Seguros and Inter DTVM. The absence of a fixed meaning for the word "inter" can also be considered to be a transferability aspect as it allows the name to be easily transferred to other sectors, categories, or across geographical and cultural boundaries.

In terms of adaptability, due to changes in customer opinions, institution values or simply the need to stay current, the brand has become more flexible to change. Its elements have become more adaptable to changes in color, shapes and applications, making them easier to update.

Regarding the protection criterion, the Inter brand is protected both in the legal sense - as it is a registered trademark - and in the competitive sense, since in the market there is no analogy to other companies with the characteristics of the brand.

\section{BANCO INTER BRAND POSITIONING}

The repositioning of a brand is important because it makes it possible to reach new markets, adapt to changes and preferences of consumers, and technological changes that can considerably affect the success of a company. In all market segments, it is possible to find consolidated brands that have experienced difficulties at some point. Some have disappeared, and others have recovered by restoring or establishing the sources of brand equity (KOTLER and KELLER, 2006).

As a competitive reference, we can highlight its young and modern positioning, applied in its points of difference. Banco Inter has a different mindset than other banks - Itaú, Bradesco, Caixa Econômica Federal, Banco do Brasil and Santander - which makes it often compared to fintechs such as Nubank and Neon. This innovative mindset enabled it to identify a new need in society, generating a differentiated experience, a 100\% digital experience. However, according to the article published by the site EXAME, its main attraction is the fact that it is free, because although large banks have more resources to invest, they retreated in the strategy and stopped offering their digital accounts for free.

Between 2016 and 2017, Inter underwent a positioning update process, during which it managed to adapt it, maintaining its brand essence, but in a current context, which really represented what the institution had become. The construction of a new identity was made in order to break the serious and traditional image, consolidated by a history of more than 20 years in the marketplace. 
Among the core values of the brand can be cited: simplicity, transparency, partnership, experience and security. On the other hand, it is noticeable the transmission of other values to customers, who see it as an extremely modern, innovative, light and practical bank. In conclusion, repositioning made the institution's values more visible. There have also been transformations in communication, both graphically and verbally, making it more friendly, relaxed and colorful.

It is also noticed that the expressions "banking revolution" and "complete, digital and free" really became the representation of brand positioning.

\section{BANCO INTER PARITY POINTS AND DIFFERENCE POINTS}

For Keller and Machado (2006), in order to establish a strong and competitive brand positioning, it is necessary to identify correct parity and difference points.

Competition parity points are attributes designed to deny competitors' points of difference. This means that the brand somehow manages to offset points of difference from the competition, giving it a stronger competitive position that is equivalent to its competitors. The points of difference are attributes with strong, favorable and exclusive associations with the brand, which are based on any type of bond or benefit made by customers.

In the case of Banco Inter, its portfolio of products and services was identified as a parity point. In order to remain competitive in the market, the institution seeks to offer in its portfolio products and services that are the same or similar to those offered by other traditional banks. Regarding the points of difference, Banco Inter offers digital platforms and accounts, without the need for face-to-face service, which makes the institution advanced compared to other banks that do not yet offer this facility to customers. Another point is the exemption of fees for any financial movement. In addition, its new positioning, which made its identity more relaxed and light, makes the institution more associated with fintechs than with traditional banks, making it a differential, especially for younger audiences.

Kapferer's prism of identity (apud PEREIRA, 2017) is a model that seeks to characterize the brand through six facets: Physical, Relationship, Reflection, Personality, Culture and Mentalisation; divided into four dimensions, in vertical and horizontal levels: Issuer and Recipient (vertical); Exteriorization and Interiorization (horizontal). This model is a unique and inseparable system that considers the aspects emitted by the brand and the interpretation of these aspects by the recipients, that is, their audiences.

The act of communicating can be considered the basis of the identity prism. The communication of a brand results in the construction of representations, both under the perception of the issuer (the brand itself) and under the perception of the receiver (the customers); and the establishment of a relationship between both parties.

After analyzing the primary and secondary data obtained during this study, it was possible to construct Banco Inter's identity prism, which to took into account the identified by the brand itself and its customers.

The Physical aspect refers to the tangible aspects of the brand that customers remember when the brand is mentioned. Through the analysis of the focus group and online social networks, the following aspects were identified: adoption of orange as an institutional color; the younger and more rounded logo; the complete portfolio of services and products; the shirt of the São Paulo football club, which acts as a reinforcement for brand visibility; and Interpig, the 
institution's mascot and used in the form of gifts, is strongly remembered and requested among customers.

The facet of the Relationship symbolizes the relationship that can arise between the brand and its audiences. It reflects the style of behavior that emerges from Banco Inter's way of acting, its delivery of products and services and its interaction with customers. The main aspects were highlighted: the service was defined as good, agile; and behavior as innovative, close, and partner - also in the suitability of verbal and textual language.

Reflex is related to how Inter is perceived by its customers. The main features mentioned are: practicality and its modern positioning, especially compared to existing traditional banks.

Personality appeals to the subjective characteristics of the institution. Brand communication, when well done, causes the attribution of human personality traits to the brand itself. Regarding this facet, the following characteristics were highlighted: balanced; dedicated; young; dynamics; Friendly and fun. The communication is made to the right extent, neither too formal nor too informal, respecting the customer's digital profile, with the concern of providing good service and adjusting the communication to make the understanding of the financial area easier and more enjoyable.

Culture is the direct link between the brand and the organization, it concerns the set of values and principles that govern Banco Inter's behavior. In this aspect, through the analysis of interviews and online social networks, values were identified as: simplicity; connectivity; transparency; safety; and innovation.

Some of these values are officially defined by the institution itself as the pillars of its positioning, as can be seen in various publications on Inter's website and social networks.

The facet of Mentalization reflects how customers feel about Banco Inter. This aspect is essential in building a brand, as it allows you to understand what really motivates customers about your brand. The outstanding characteristics were: independent and modern, that is, the feeling of independence in self-service associated with the modern and innovative aspect of digital access and service offerings. It is noted that both perceptions are similar, meaning that the brand is able to adequately convey the expected identity, which enables the search for coherence, in a unity between the brand, communication and positioning.

\section{FINAL CONSIDERATIONS}

Faced with a world undergoing constant transformations - technological, social, cultural, economic and political - for brands, the use of branding strategies became indispensable. The success or failure of a brand depends on its ability to understand how these transformations affect the market and people, and thus find ways to adapt to them. Today, consumers seek not only to consume products and services, but also to know the essence of the brand, its discourse and its positioning. Thus, this study aimed to problematize the relationship of a brand's positioning and its visibility in the market, an essential aspect for its growth.

Based on the information obtained, it was possible to realize that Banco Inter's managers had the ability to fully and comprehensively analyze the internal scenarios - a position that did not speak with their values and publics - and external to the institution - an opportunity to grow in the Banking market -; coming to the conclusion that it was time for a change. From the analysis of the institution's history, it was concluded that the change did not imply that the brand had 
made mistakes or had no market strength. Thus, it was only used as a strategy for its evolution and strengthening.

Most of the specific objectives were achieved through interviews and focus group. Through interviews with the branding professional, Noele Karime, it was identified that the repositioning process happened spontaneously and gradually, through the identification of a marketing opportunity, having as its main motivator the goal of translating, through its image , the values already adopted by the institution in an attempt to show its audiences the changes that occurred internally and in the products and services offered. In addition, it was possible to survey the first actions and strategies - event; physical changes in headquarters, distribution of educational and promotional materials; massive dissemination in the press; among others carried out during the implementation and dissemination of Banco Inter's new brand.

The focus group application broadly aggregated perceptions about customers' view of the Intermedium and Inter brands. The opinions and comments made by the participants were extremely important and relevant in understanding, especially regarding the recognition of brands, presence in the market and the results obtained after repositioning. For the group's participants, who only became clients of Banco Inter after the repositioning, it is noticeable the increase of the institution's visibility over the last years.

It can be seen from the results of this study that branding strategies are essential for positioning a brand in front of its public. Banco Inter has been working very well on its image after the change, making the institution's growth noticeable, both in terms of structure and number of employees, as well as market recognition and number of customers.

It is believed that this work is important, in the current context, where brands need to review their positioning in order to be closer to their customers and adapt to the changing market and their demands. However, much remains to be studied on this topic. The importance of following the strategies and actions carried out by Banco Inter is stressed. Society and the market certainly undergo several transformations, and this influences both brands and consumers. In this sense, the strategies and actions employed by brands may not be effective in the future, making a new positioning necessary.

\section{References}

BANCO INTER; Disponível em: <https://www.bancointer.com.br/>. Acesso em: 14 out. 2018.

BANCO INTER RELAÇÕES COM INVESTIDORES. Disponível em: <https://ri.bancointer. com.br/default.aspx?\#obanco2>. Acesso em: 2 nov. 2018.

BANCO INTERMEDIUM INAUGURA 'TARIFÔMETRO', EM BELO HORIZONTE. O Tempo; 2016. Disponível em: <https://www.otempo.com.br/banco-intermedium-inaugura-tarif\%C3\%B4 metro-em-belo-horizonte1.1375009>. Acesso em: 2 nov. 2018.

CRESCIMENTO DO BANCO INTER E O PATROCÍNIO AO SÃO PAULO, O. Mkt Esportivo; 2019. Disponível em: <http://www.mktesportivo.com/2018/01/o-crescimento-do-banco-inter-e-o-patrocinio-ao-sao-paulo/>. Acesso em: 15 jun. 2019.

ENTENDA O COMPORTAMENTO DOS CONSUMIDORES. SEBRAE; 2015. Disponível em: $<$ http://www.sebrae.com.br/sites/PortalSebrae/artigos/entenda-o-comportamento-dosconsumi dores,4c73ce6326c0a410VgnVCM1000003b74010aRCRD>. Acesso em: 13 out. 2018.

ESTRATÉGIA DO BANCO INTER CONTRA OS GIGANTES DO MERCADO, A. Exame; 2017. Disponível em: < https://exame.abril.com.br/negocios/a-estrategia-do-banco-inter-contra-os-gigantes-do-mercado/>. Acesso em: 15 jun. 2019.

INTERMEDIUM SERÁ O MAIOR PATROCINADOR DO SÃO PAULO ATÉ 2020. Valor Econômico; 2018. Disponível em: <https://www.valor.com.br/empresas/4970656/intermedium-sera-o-maior-patrocinador-do-sao-paulo-ate2020>. Acesso em: 2 nov. 2018 
KELLER, Kevin Lane; MACHADO, Marcos; Gestão Estratégica de Marcas; tradução Arlete Simille Marques. São Paulo: Pearson Prentice Hall, 2006.

KOTLER, Philip; KELLER, Kevin Lane; Administração de Marketing; 12ª edição; tradução Mônica Rosenberg, Brasil Ramos Fernandes, Cláudia Freire; revisão técnica Dilson Gabriel dos Santos. São Paulo: Pearson Prentice Hall, 2006.

LAVILLE, Christian; DIONNE, Jean. A construção do saber: manual de metodologia da pesquisa em ciências humana. Porto Alegre: Artmed Editora Ltda., 1999

LOPES, Laís Bradacz; Reposicionamento de Marca: Estudo Multicasos no Setor Alimentício de Santa Catarina. 2015. 84 folhas. Trabalho de Conclusão de Curso, Universidade Federal de Santa Catarina, Florianópolis, 2015.

NOVA IDENTIDADE VISUAL DO BANCO INTER. Laboratório de Conexões Intermidiáticas (LABCON); 2017. Disponivel em: < http://labcon.fafich.ufmg.br/nova-identidade-visual-banco-inter/>. Acesso em: 14 out. 2018. NOVO COMPORTAMENTO DO CONSUMIDOR DIGITAL, O. Transformação Digital; 2018. Disponível em: $<$ https://transformacaodigital.com/novo-comportamento-do-consumidor-digital/>. Acesso em: 18 out. 2018.

PEREIRA, Paula Fernanda Prado; Prisma de Identidade de Marca: perspectiva para evolução do modelo. 2017. 105 folhas. Trabalho de Conclusão de Doutorado, Pontifícia Universidade Católica de São Paulo, São Paulo, 2017.

REBRANDING BANCO INTER. Laboratório de Conexões Intermidiáticas (LABCON); 2017. Disponivel em: <http://labcon.fafich.ufmg.br/rebranding-banco-inter/>. Acesso em: 14 out. 2018.

SAMPAIO, Rafael. Marcas de A a Z: como construir e manter marcas de sucesso: um guia para fazer da sua marca a principal força do seu negócio; 6a edição. Rio de Janeiro: Elsevier, 2002.

SAMPAIO, Rafael. Marcas de A a Z: como construir e manter marcas de sucesso. Rio deJaneiro: Campus, 2002 TRANSFORMAÇ̃̃O DIGITAL BANCÁRIA: COMO OS BANCOS ESTÃO SE TORNANDO DIGITAIS?. Inteligência Rock Content; 2017. Disponível em: <https://inteligencia.rockcontent.com/transformacao-digital-bancaria/>. Acesso em: 19 set. 2018

TRANSFORMAÇÃO DIGITAL NO FINANCEIRO É OBRIGATÓRIA, A - E URGENTE!. Transformação Digital; 2018. Disponível em: <https://transformacaodigital.com/a-transformacao-digital- no-financeiro-e-obrigatoria-eurgente/>. Acesso em: 17 out. 2018.

TAVARES, Mauro Calixta; Gestão de Marcas: construindo Marcas de Valor. São Paulo: Harbra, 2008.

TELLES, Talita Rodrigues; Havaiana - Por que todo mundo usa?: A influência do reposicionamento na alteração do patrimônio da marca. 2008. 107 folhas. Trabalho de Conclusão de Curso, Universidade Federal de Goiás, Goiânia, 2008

TYBOUT, Alice M.; CALKINS, Tim; Branding: Gestão de Marcas; 1ํe edição; tradução Arlete Simille Marques; revisão técnica Carlos Eduardo Lourenço. São Paulo: Saraiva, 2018.

UM OLHAR DIGITAL SOBRE O CONSUMIDOR. Meio \& Mensagem; 2012. Disponivel em: <http://www.meioemensagem.com.br/home/marketing/2012/02/07/um-olhar-digital-sobre-oconsumidor.html>. Acesso em: 16 set. 2018. 